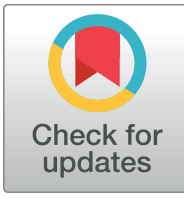

\section{OPEn ACCEss}

Citation: Sekeyová Z, Danchenko M, Filipčík P, Fournier PE (2019) Rickettsial infections of the central nervous system. PLoS Negl Trop Dis 13(8): e0007469. https://doi.org/10.1371/journal. pntd.0007469

Editor: Abdallah M. Samy, Faculty of Science, Ain Shams University (ASU), EGYPT

Published: August 29, 2019

Copyright: ๑ 2019 Sekeyová et al. This is an open access article distributed under the terms of the Creative Commons Attribution License, which permits unrestricted use, distribution, and reproduction in any medium, provided the original author and source are credited.

Funding: This work was supported by the following projects: APVV-0280-12, "Štefanik“ APVV-SK-FR2017-0005, VEGA 2/0010/19, and the French National Research Agency under the program "investissements d'avenir," reference ANR-10IAHU-03. The funders had no role in study design, data collection and analysis, decision to publish, or preparation of the manuscript.

Competing interests: The authors have declared that no competing interests exist.

REVIEW

\title{
Rickettsial infections of the central nervous system
}

Zuzana Sekeyová ${ }^{1}$, Monika Danchenko ${ }^{1}$, Peter Filipčík ${ }^{2}$, Pierre Edouard Fournier $\circledast^{3,4}$ *

1 Institute of Virology, Slovak Academy of Sciences, Dubravska cesta, Bratislava, Slovakia, 2 Institute of Neuroimmunology, Slovak Academy of Sciences, Dubravska cesta, Bratislava, Slovakia, 3 Aix-Marseille Univ, IRD, AP-HM, SSA, VITROME, IHU Mediterranée-Infection, Marseille, France, 4 Centre National de Référence des Rickettsia, Coxiella et Bartonella, IHU Mediterranée-Infection, Marseille, France

* pierre-edouard.fournier@univ-amu.fr

\section{Abstract}

As a result of migrations and globalization, people may face a possible increase in the incidence of central nervous system rickettsial infections (CNS R). These diseases, caused by Rickettsia species and transmitted to humans by arthropod bites, are putatively lethal. However, the diagnosis of CNS R is challenging and often delayed due to their nonspecific clinical presentation and the strict intracellular nature of rickettsiae. Furthermore, transfer of rickettsiae to the brain parenchyma is not yet understood. The aim of this review is to analyze and summarize the features and correlated findings of CNS R in order to focus attention on these intriguing but frequently neglected illnesses. We also incorporated data on CNS infections caused by Rickettsia-related microorganisms.

\section{Introduction}

Recent reports have warned about the impact of global warming in facilitating the transmission of certain vector-borne infectious diseases. However, due consideration must be taken of the role played by other variables, such as the increase in international travel, migration, and trade, with the risk of importing parasites and vectors with the goods [1]. Rickettsioses are common tick-, flea-, or mite-borne bacterial illnesses with a clinical spectrum ranging from a mild febrile illness to potentially life-threatening complications [2,3]. Rickettsial infections can affect many organs, including the central nervous system (CNS) [4]. The most common neurological manifestations reported in rickettsial infections include meningitis, encephalitis, and acute disseminated encephalomyelitis [5]. However, unilateral facial nerve palsy [6], cerebral infarction [7], or visual loss [8] have also been diagnosed. Therefore, it is critical to enhance the awareness of physicians worldwide on CNS rickettsial infections (CNS R).

Few studies on the pathogenesis of rickettsiae for the CNS have been conducted. In neurons cultured in vitro, rickettsiae have been demonstrated to cause a profound morphological deterioration and intracellular decrease of ATP [9]. In addition, it was demonstrated that rickettsiae can persist and reappear after a relatively long time in the CNS in immunocompromised mice, causing a fatal neuroinflammation [10]. This suggests a potential neuropathic role of rickettsiae. However, data on rickettsial infections in a context of degenerative CNS diseases, which usually result from mixed neuropathologies and present with multiple symptoms, are 
scarce in the literature, and to date, no association between neurodegenerative diseases and rickettsial infections has been demonstrated.

In this article, we systematically reviewed the literature reporting cases of CNS R to provide scientists and healthcare providers with a summary of the current knowledge on and challenges posed by these diseases. We also included data on Orientia, Anaplasma, and Ehrlichia species, which are phylogenetically close to Rickettsia species.

\section{Literature search and selection criteria}

We searched PubMed with the following Medical Subject Heading terms: "rickettsia" (9,504 results); "rickettsia" AND "central nervous system" (169 results); and "rickettsia" AND "central nervous system" AND review (5 results). The search was limited to articles published in English between January 1, 1960, and February 28, 2019. In addition, no online book or book chapter in relation to this subject was identified.

We also searched PubMed with the Medical Subject Heading terms: "orientia" AND "human" (945 results); "ehrlichia" AND "human" (1,421 results); "anaplasma" AND "human" (1,385 results); "orientia” AND "human” AND "central nervous system" (26 results); "ehrlichia" AND "human" AND "central nervous system" (10 results); and "anaplasma” AND "human" AND "central nervous system" (3 results).

\section{Epidemiology of rickettsial diseases}

Rickettsiae are strictly intracellular bacteria that are vectored by various arthropods. To date, 18 species are recognized human pathogens, 12 of which cause CNS R (Fig 1). To these pathogenic Rickettsia species may be added O. tsutsugamushi and O. chuto that are phylogenetically closely related and are still often referred to as rickettsiae. Rickettsioses are zoonotic diseases that distributed worldwide (Fig 2) in foci of endemicity (Table 1), with sporadic and often seasonal outbreaks [11]. However, R. prowazekii has the potential to reemerge as outbreaks in human populations living in close proximity and impoverished conditions [12] (Fig 3).

\section{Clinical manifestations of rickettsial infections}

Spotted fever rickettsioses typically present with a triad made of fever, inoculation eschar(s), and generalized cutaneous rash. However, infected patients may develop other clinical pictures, including nonspecific flu-like symptoms, isolated fever, myalgia, cough, generalized lymphadenopathy, abdominal pain, and a variety of neurological symptoms that are described next.

Most commonly, patients recover without sequellae. However, the clinical presentation of rickettsial diseases may vary from mild to very severe, with the case-fatality rate for highly virulent rickettsiae ranging from $2 \%$ to $30 \%$ [13]. The severity of rickettsial disease has been associated with differences in pathogen virulence and host-related factors (e.g., age, delayed diagnosis, hepatic and renal dysfunction, CNS and lung involvement) [14]. Regarding speciesspecific variations in virulence, studies have suggested that these differences may be linked to the degree of genomic degradation. In a comparison of 4 species exhibiting distinct virulence profiles, the most virulent Rickettsia sp. exhibited the most drastically reduced and degraded genomes compared with closely related species of milder pathogenesis [15].

\section{Mechanisms of bacterial entry into the CNS}

The brain-blood barrier (BBB) at the level of brain microvessel endothelium is the major site of blood-CNS exchange. The mechanisms of bacterial entry into the CNS are divided 


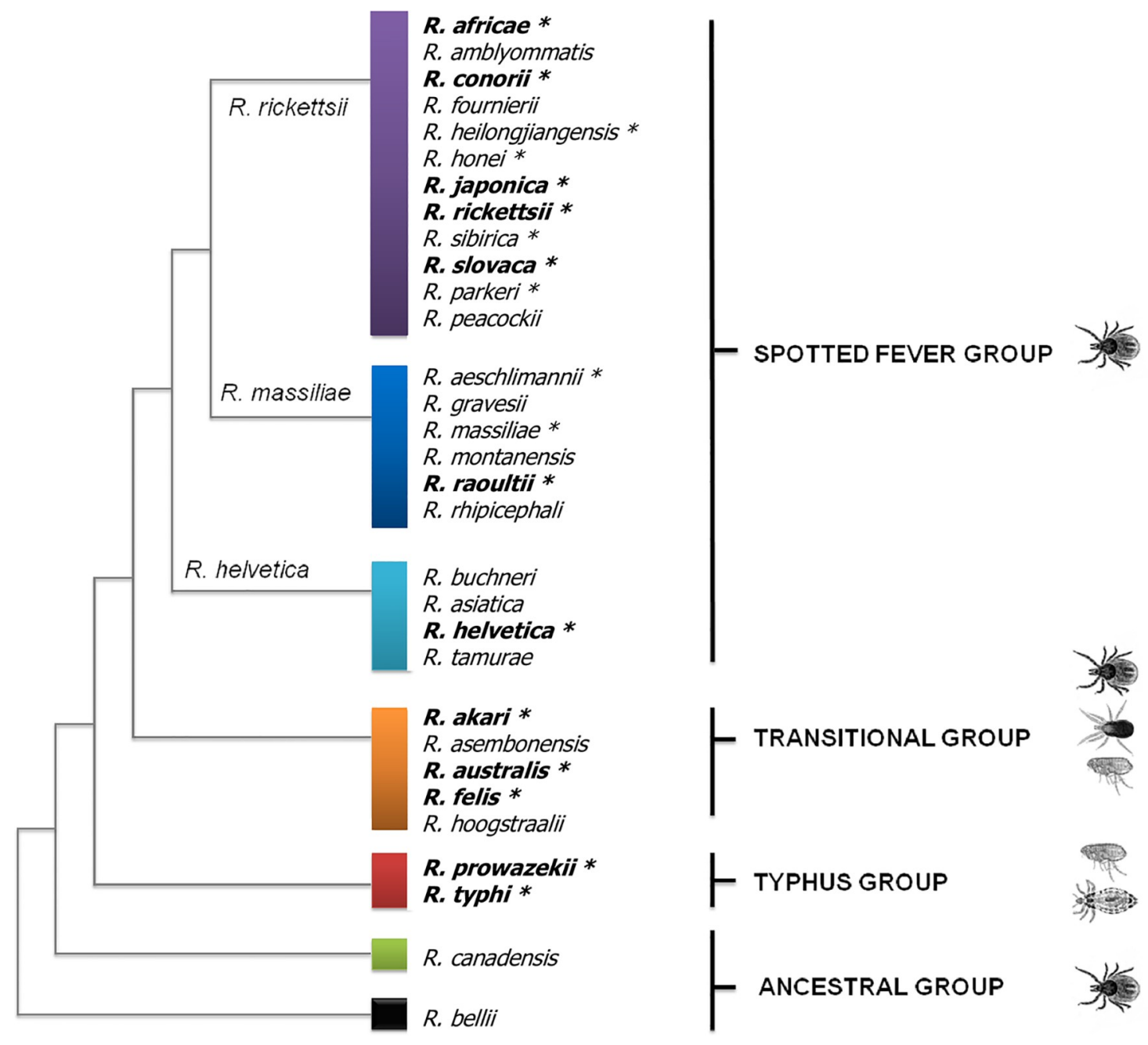

Fig 1. Phylogenetic tree of Rickettsia species inferred from the comparison of concatenated sequences from the gltA and sca4 genes. Rickettsia species are distributed into 4 groups: SFG, TRG, TG, and AG. SFG rickettsiae are mostly associated with ticks; TG rickettsiae with human body lice ( $R$. prowazekii) and rat fleas (R. typhi); TRG rickettsiae with ticks, cat fleas, or mites; and AG rickettsiae with ticks. Asterisks mark pathogenic species, and bold letters indicate species causing CNS infections. AG, ancestral group; CNS, central nervous system; SFG, spotted fever group; TG, typhus group; TRG, transitional group.

https://doi.org/10.1371/journal.pntd.0007469.g001

according to whether they break the integrity of BBB cells (which consist of microvascular endothelial cells of the brain, pericytes, and astrocytes) or interact with epithelial cells of the blood-choroid barrier. Mechanisms used by pathogens to enter the CNS are usually classified according to the involved cellular route $[16,17]$. These cellular entry routes are listed as intercellular or paracellular (passing between cells), transcellular (the intracellular mode), or leukocyte-facilitated in infected phagocytes (which is a "Trojan horse"-like mechanism) $[18,19]$. Rickettsial neuroinvasion occurs during the systemic phase of the disease and typically follows bacterial dissemination via the bloodstream. As other intracellular microorganisms, rickettsiae might use a transcellular approach, which is supported by the fact that bacterial replication takes place within endothelial cells. Other studies have demonstrated that bacterial pathogens (extra- and intracellular) can reach the $\mathrm{BBB}$ and are recognized by antigen-presenting cells through binding to Toll-like receptors (Fig 4). 


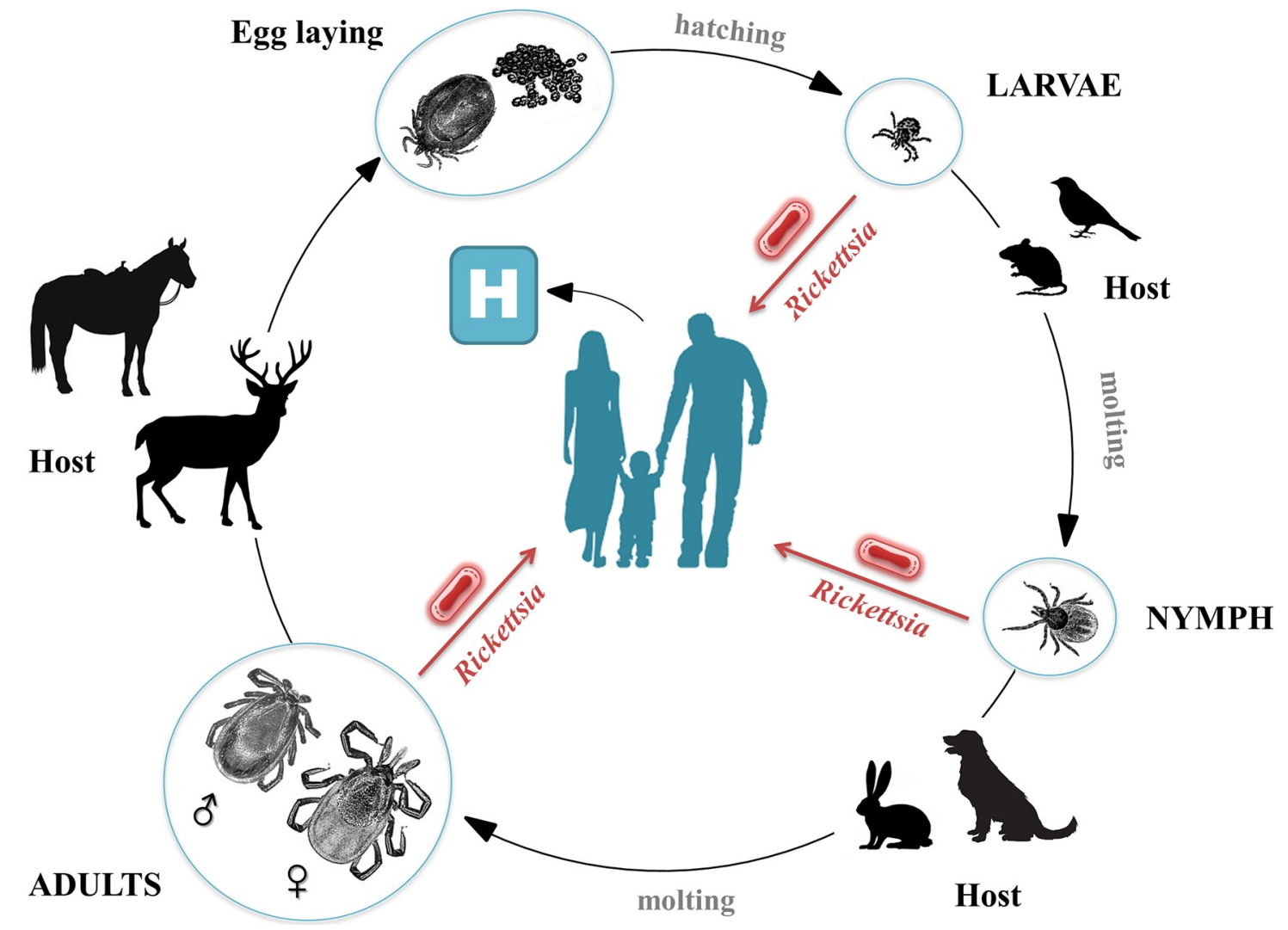

Fig 2. Developmental cycle and host range of Rickettsia-infected ticks. Ticks are the main vectors and constitute a threat of rickettsial infection regardless of their development stage (larvae, nymphs, or adults). Many factors play a role in the epidemiology of tick-borne rickettsioses, including the prevalence and species diversity of rickettsiae in mammals [149-153] and the dispersion of infected ticks by migratory birds [154].

https://doi.org/10.1371/journal.pntd.0007469.g002

They induce the activation of nuclear factor-kappa B- or mitogen-activated protein kinase pathways and subsequently up-regulate leukocyte populations and express numerous proteins involved in inflammation and the immune response [16,18]. However, the precise molecular mechanisms of rickettsial entry into the CNS are not yet described.

\section{Treatment of rickettsioses}

The most efficient antibiotics to cure rickettsioses are tetracycline derivatives, primarily doxycycline. The daily dose, $200 \mathrm{mg}$, is usually administered orally and is sufficient to cure rickettsioses. Treatment duration is 7 days or until 2 days after apyrexia is obtained [20,21]. In severe forms, intravenous doxycycline may be used. Alternatively, chloramphenicol and macrolides (azithromycin, clarithromycin, and roxytromycin) can be prescribed for treating rickettsial diseases [22,23]. As a consequence, empirical therapy for CNS infections most often does not include antibiotics active on rickettsiae.

\section{Neuropathology in the framework of rickettsial diseases Spotted fever group rickettsiae}

In spotted fever group (SFG) rickettsioses, encephalitis is underdiagnosed due to underrecognition and low sensitivity of serologies at the time of early symptoms [24]. Therefore, it is 
Table 1. Geographical distribution and arthropod vectors of Rickettsia and Orientia species causing CNS infections.

\begin{tabular}{|c|c|c|c|c|}
\hline Species (type strain) & Disease & Vector & Distribution & $\begin{array}{c}\text { Genome sequence accession } \\
\text { number* }\end{array}$ \\
\hline R. africae (ESF-5) & ATBF & $\begin{array}{c}\text { Amblyomma and Rhipicephalus } \\
\text { ticks }\end{array}$ & $\begin{array}{l}\text { Sub-Saharan Africa, West } \\
\text { Indies }\end{array}$ & NC_012633 \\
\hline R. akari (Hartford) & Rickettsialpox & L. sanguineus mites & $\begin{array}{l}\text { North America, Asia, } \\
\text { Europe }\end{array}$ & NC_009881 \\
\hline R. australis (Cutlack) & QTT & Ixodes ticks & Australia & NC_017058 \\
\hline R. conorii (Malish 7) & MSF & Rhipicephalus sanguineus ticks & Europe, North Africa, Asia & NC_003103 \\
\hline $\begin{array}{l}\text { Rickettsia felis (Marseille- } \\
\text { URRWFXCal }_{2} \text { ) }\end{array}$ & Flea-borne rickettsiosis & Mostly C. felis & Worldwide & NC_007109.1 \\
\hline Rickettsia helvetica (C9P9) & Unnamed rickettsiosis & Ixodes sp. & Europe, Asia, North Africa & NZ_CM001467 \\
\hline Rickettsia japonica $(\mathrm{YH})$ & $\begin{array}{l}\text { Japanese/Oriental spotted } \\
\text { fever }\end{array}$ & Haemaphysalis ticks & Asia & NC_016050 \\
\hline Rickettsia raoultii (Khabarovsk) & TIBOLA & Dermacentor and Ixodes ticks & Europe & NZ_CP010969 \\
\hline Rickettsia rickettsii (Sheila Smith) & RMSF & Mostly Dermacentor ticks & North and Central America & NC_009882 \\
\hline Rickettsia slovaca (13-B) & TIBOLA & Dermacentor ticks & Europe, Asia & NC_016639 \\
\hline R. prowazekii (Madrid E) & Epidemic typhus & $\begin{array}{l}\text { Pediculus humanus humanus } \\
\text { lice }\end{array}$ & $\begin{array}{c}\text { Africa, Russia, South } \\
\text { America }\end{array}$ & NC_000963 \\
\hline R. typhi (Wilmington) & Murine/endemic typhus & X. cheopis fleas & Worldwide & NC_006142 \\
\hline O. tsutsugamushi (Ikeda) & Scrub typhus & Leptotrombidium mites & Asia & NC_010793 \\
\hline
\end{tabular}

${ }^{*}$ All genomes were imported from GenBank (http://www.ncbi.nlm.nih.gov/genome/)

Abbreviations: ATBF, African tick bite fever; CNS, central nervous system; MSF, Mediterranean spotted fever; QTT, Queensland tick typhus; RMSF, Rocky Mountain spotted fever; TIBOLA, tick-borne lymphadenopathy

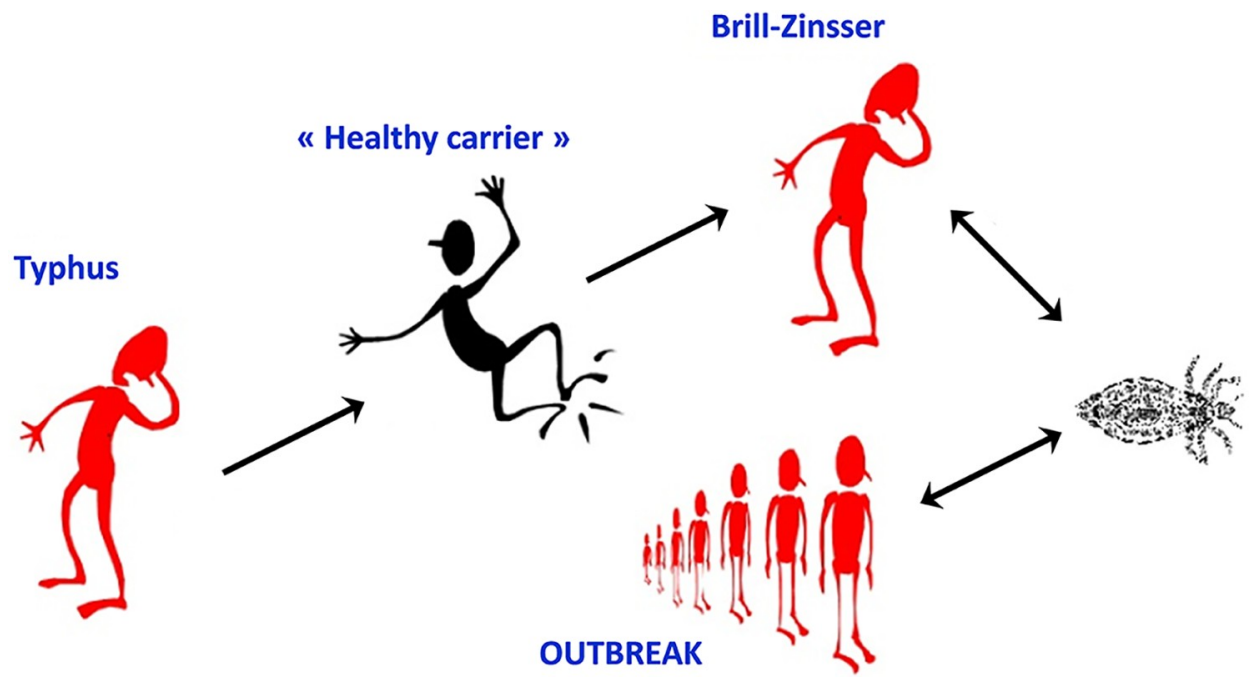

Fig 3. Body lice as the cause of typhus reemergence. $R$. prowazekii is classified as a category B bioterrorism agent. It is stable in dried louse feces and can be transmitted through aerosols. Detection of the pathogen in body lice is crucial for monitoring the transmission risk to humans. However, Brill-Zinsser disease, a relapsing form of epidemic typhus that may develop as sporadic cases up to 40 years after the initial acute infection, is unrelated to louse infestation but to stress or a waning immune system that initiates the reactivation of an earlier and latent infection. Patients developing Brill-Zinsser disease may, in turn, be the source of new outbreaks when conditions facilitate louse infestation and transmission [155]. The mechanism of R. prowazekii latency has not been established. Brill-Zinsser disease should be considered as a possible diagnosis for acute fever in any patient who has lived in an area where epidemic typhus was endemic [156].

https://doi.org/10.1371/journal.pntd.0007469.g003 


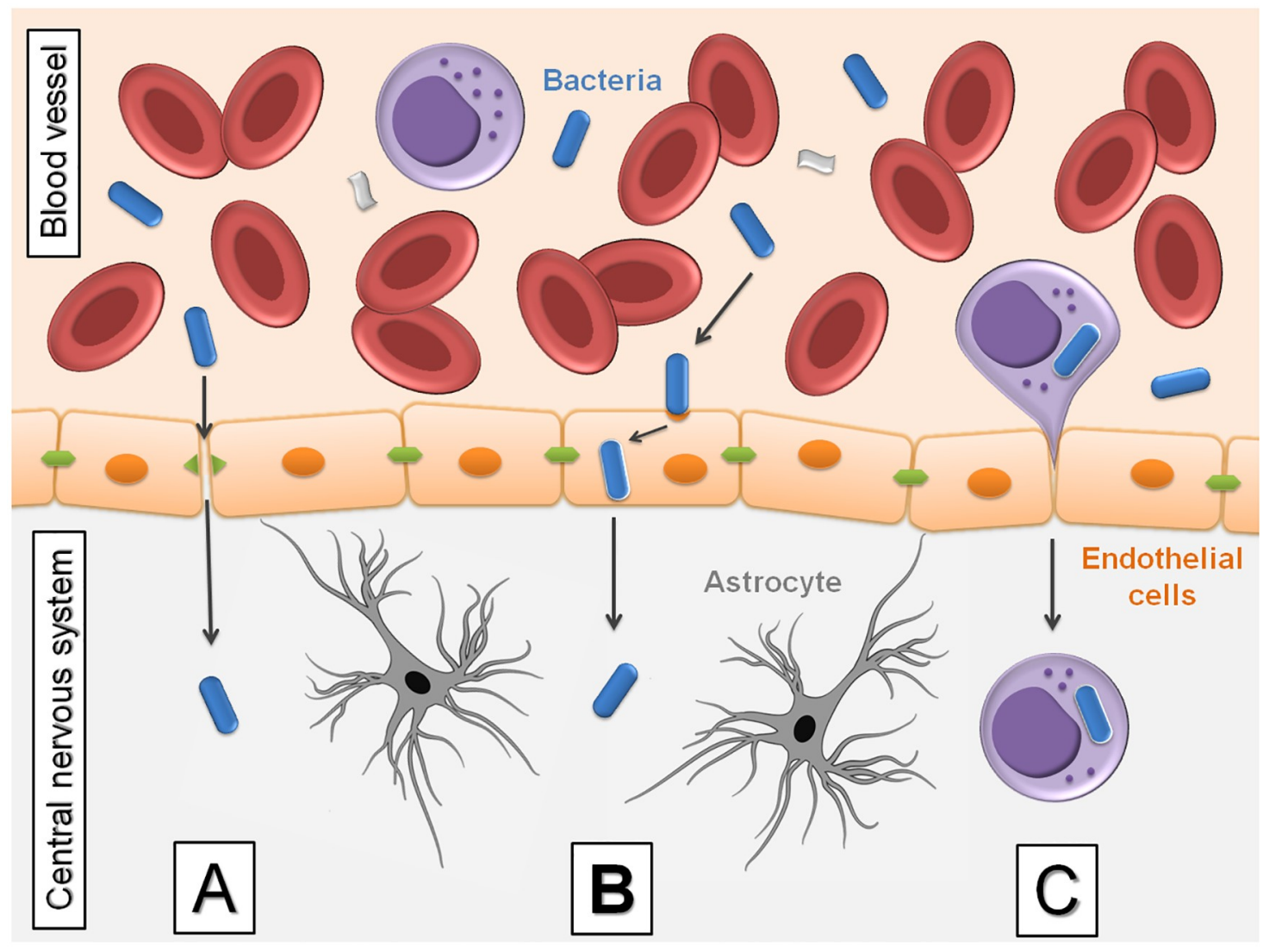

Fig 4. Mechanisms of bacterial penetration through the blood-brain barrier. (A) Intercellular or paracellular, described in extracellular pathogens. The physical barrier formed by endothelial tight junctions is disturbed by bacterial penetration. (B) Transcellular, passing through cells, e.g., direct invasion of endothelial cells. In this scenario, blood-borne bacteria directly invade CNS endothelial cells. (C) By leukocytes, within infected macrophages, named "Trojan horse" mechanism. Infected leukocytes adhere to endothelial cells, allowing the spread of bacteria or, alternatively, leukocytes can transmigrate and deliver bacteria to the CNS parenchyma. CNS, central nervous system.

https://doi.org/10.1371/journal.pntd.0007469.g004

difficult for clinicians to recognize the clinical, biological, and neuroimaging features of this type of encephalitis [25].

\section{Rocky Mountain spotted fever}

Rocky Mountain spotted fever (RMSF), caused by R. rickettsii, frequently presents with neurological symptoms $[26,27]$. The CNS notably appears to be one of the major systems involved during the latest stages of RMSF pathogenesis [28].

The onset of symptoms is usually abrupt, with severe headache, fever, chills, myalgias, arthralgias, and prostration. Neurological symptoms are frequently a prominent feature. Headache, restlessness, insomnia, and back stiffness are common. Delirium or coma alternating with restlessness is present during the peak of fever [26,27,29-31]. Encephalitis, which may be fatal, is a frequent manifestation in case of delayed diagnosis and treatment [32]. In addition, several authors have described severe sequelae in patients who survived $R$. rickettsii infection, including hemiplegia, deafness, visual disturbance, slurred speech, mental confusion, and cranial neuropathies that may persist for a few weeks following recovery [33-37].

Histological studies have highlighted that the pathologic changes in RMSF are most severe in the skin, but the heart, lungs, and CNS also are involved. The brain is edematous, and 
minute petechial hemorrhages are present. The characteristic microscopic lesions are small round nodules composed of elongated microglia, lymphocytes, and endothelial cells $[29,38,39]$. These are scattered diffusely through the brain in close relation to small vessels. Vessels in the center of the lesions show severe degeneration. Endothelial cells are swollen, and the lumen may be occluded. Areas of focal necrosis are common as the result of thrombosis of small arteries. Some degree of perivascular infiltration without the presence of nodules may be seen in both the meninges and brain parenchyma [29].

To the best of our knowledge, there is just one report of experimental in vitro rickettsial infection of neuronal cells. Joshi and Kovacs [40] demonstrated that neurons are efficiently infected by $R$. rickettsii and that the infection causes significant neuronal apoptotic cell death. A double-immunofluorescent staining technique was employed to identify infected neurons, using anti-R. rickettsii serum and a neuron-specific (antineuronal $\beta$-III isoform of tubulin [anti-TuJ1]) antibody. The extent of apoptotic cell death of immunocytochemically identified neurons was determined by terminal deoxynucleotidyl transferase-mediated digoxigenindUTP nick-end labelling (TUNEL) assay. Primary cultures of rat cerebellar granular neurons were infected (approximately $65 \%$ of neurons) during a 6-hour exposure to R. rickettsii, and the infection induced widespread neuronal degeneration. To verify that the observed neuronal degeneration was $R$. rickettsii-induced, primary cultures of rat cerebellar granular neuron cultures were exposed to $R$. rickettsii in the presence of tetracycline. The authors also included $R$. rickettsii infection of endothelial cells as a control for infection and infection-induced apoptotic cell death [40].

The CNS is also a crucial target in other rickettsial diseases [41,42]. It has been demonstrated by a specific immunohistochemistry technique, during the development of mousemodel studies, that rickettsiae reach brain tissues when injected intravenously [43]. Such studies demonstrate that rickettsiae are able to cross the blood-brain barrier to reach brain tissues. The other rickettsial infections that may affect the nervous system exhibit pathological and clinical changes similar to those of RMSF [29]. In rickettsial meningitis, the cerebrospinal fluid shows pleocytosis with lymphocyte predominance, hypoglycorrhachia, and hyperproteinorrhachia.

\section{Mediterranean spotted fever}

Mediterranean spotted fever (MSF), also known as Boutonneuse fever and Marseilles fever, is caused by $R$. conorii. Although usually a benign and self-limiting exanthematous febrile illness [44-47], MSF has a fatality rate of $2 \%$ to $7 \%$ among hospitalized patients [48]. In large MSF case series from France and Spain, patients with severe and fatal forms of the disease developed complications, including acute renal failure, thrombocytopenia, myocarditis, pneumonitis, gastric hemorrhage, shock, and multiple organ failure [44-47,49]. Furthermore, a few reports in the literature have described CNS involvement in the course of MSF, presenting as meningitis [50,51], encephalitis [45,47,49,50,52,53], meningoencephalitis [47,54-56], or myelitis [50]. Among the patients who survived these severe forms, only 2 did not suffer sequelae. Sequelae were severe, despite an appropriate doxycycline treatment of $200 \mathrm{mg}$ every 12 hours [54,57].

\section{Japanese spotted fever}

Japanese spotted fever (JSF), caused by R. japonica, was first reported in 1984 [58]. This rickettsial disease is characterized by high fever, rash, and inoculation eschar at the tick bite site [58]. JSF is clinically similar to scrub typhus, caused by O. tsutsugamushi, but often with a more severe course [58]. CNS involvement is rare, but cases complicated by pneumonia or meningoencephalitis have been reported [59-61]. There have been only 5 JSF reported cases with CNS 
involvement [62-64]. The first fatal case was reported by Kodama and colleagues in 2002 [65]. All patients exhibited fever and mental disturbance, including 3 patients with nuchal rigidity and 3 patients with seizures. All patients had aseptic meningitis [66].

\section{Tick-borne lymphadenopathy}

$R$. slovaca and $R$. raoultii cause a rickettsiosis that has successively been named tick-borne lymphadenopathy (TIBOLA) [67-69], Dermacentor-borne necrosis erythema and lymphadenopathy (DEBONEL) [70-73], and then scalp eschar and neck lymphadenopathy after tick bite (SENLAT) [74]. The first R. slovaca isolate was cultivated from a D. marginatus tick collected in central Slovakia and was initially considered nonpathogenic $[67,75,76]$. However, in $1997, R$. slovaca was identified as the cause of a clinical entity combining scalp eschar and neck lymphadenopathy after a tick bite [76]. After MSF, TIBOLA is nowadays the most prevalent tick-borne rickettsiosis in Europe [77].

This syndrome is defined by the association of a tick bite and an inoculation eschar to the scalp, surrounded by a circular erythema, and painful regional lymphadenopathies [78]. The enlarged lymph nodes are located in the draining region of the tick bite, characteristically in the occipital region and/or behind the sternocleidomastoidal muscle. Although rare, the most frequent general symptoms are fever, nuchal lymphadenopathy, fatigue, dizziness, headache, sweat, myalgia, arthralgia, and loss of appetite [68,79]. Symptoms suggestive of acute encephalitis with febrile relapses and a persistence of neurasthenic disorders have also been reported $[68,80]$.

Although R. slovaca was the first demonstrated agent of TIBOLA [76] and was isolated from a patient [81], other Rickettsia species were suspected to be involved in the disease in Spanish reports $[71,82]$. In 2008, $R$. raoultii DNA was detected in a tick taken from the scalp of a patient with TIBOLA [83]. In 2009, Parola and colleagues reported 6 more cases of $R$. raoultii infection [84]. To date, $R$. raoultii has been described as causing a milder form of TIBOLA than R. slovaca [84].

\section{African tick bite fever}

African tick bite fever (ATBF), caused by R. africae, is the most common rickettsiosis in travelers to sub-Saharan Africa and also the most important rickettsiosis worldwide in terms of numbers of cases per year [85-87]. The disease is most commonly mild and self-limiting without any sequellae. However, in 2006, Jensenius and colleagues reported 6 patients with evidence of long-lasting subacute neuropathy following ATBF contracted during a safari to southern Africa [88]. Of these, 3 developed radiating pain, paresthesia, and/or motor weakness of the extremities; 2 had hemifacial pain and paresthesia; and 1 developed unilateral sensorineural hearing loss.

\section{R. helvetica infection}

R. helvetica was first isolated from Ixodes ricinus ticks in Switzerland in 1979 [89], but its description as a distinct species of the SFG was confirmed only in 1993 [90]. Initially, the organism was considered as nonpathogenic. However, several patients with a mild and selflimiting disease associating fever, headache, and myalgia had serological evidence of $R$. helvetica infection [91]. Human cases have been reported in several European countries, e.g., Sweden [92] (proven by PCR and DNA sequencing), France [91], Switzerland [93], and Italy [94] (proven by serological findings). However, a more severe clinical disease has been reported and may be associated with severe symptoms such as CNS disorders $[95,96]$ (verified by PCR 
in the cerebrospinal fluid, together with serologic evidence). $R$. helvetica was even cultured from a patient with subacute meningitis [97].

\section{Typhus group rickettsiae}

Epidemic typhus. R. prowazekii, the agent of epidemic typhus, causes frequent neurological manifestations. These include an agitated delirium that, when untreated, may progress to death. A severe headache is almost always present. Neurological complications include seizures, confusion, and coma. In severe cases, patients develop meningoencephalitis, with meningism, tinnitus, and hyperacusis, followed by deafness, dysphoria, and agitation. In BrillZinsser disease, the recurrent form of epidemic typhus that may occur months to years after the initial infection, symptoms are similar to the primary infection, although generally milder $[29,98]$.

Murine typhus. R. typhi, the causal agent of murine or endemic typhus, is transmitted to humans by the rat flea Xenopsylla cheopis. It is most often a mild illness, but severe forms have been reported in refugee camps, and a fatal case in the United Kingdom was infected in Spain [99]. There is a considerable variability in the frequency of neurological manifestations of murine typhus, ranging from $2 \%$ to $20 \%$ of cases $[100,101]$. Headache is common, but meningitis and encephalitis are occasionally reported [102]. Mental confusion, seizures, stupor, and ataxia may occur infrequently [101,103-105]. In some cases, systematic signs and symptoms may be minimal, and neurological manifestations may be the primary clinical manifestations of R. typhi infection. No neurologic sequellae have been reported in the past [29,42]. However, recently, an abducens nerve palsy and meningitis induced by $R$. typh $i$ has been described [106].

\section{Transitional group rickettsiae}

Rickettsialpox. Rickettsialpox was first described in 1946 in New York City, New York [107]. The etiological agent is $R$. akari, transmitted by the mite Liponyssoides sanguineus [108]. Rickettsialpox is still occurring in the state of New York [109,110], and European cases of $R$. akari infection were reported in Ukraine [111], Croatia [112], and Northern Europe [113]. Clinical signs of R. akari infection develop about 7 to 10 days after an infected bite. At the mite inoculation site, a vesicle appears, which dries up, leaving a scar. High fever $\left(\leq 39.4{ }^{\circ} \mathrm{C}\right)$ occurs suddenly, along with severe headache and myalgias (especially in the back). A generalized papular rash develops, which can also be vesicular, resembling chickenpox. Other signs of the disease include regional lymphadenopathy, nausea, and neurological symptoms such as meningitis, photophobia, dizziness, eye movement, and neck stiffness. The disease is self-limiting, usually without complications, but myalgias and headache may persist for 2 more weeks after the rash [114].

Queensland tick typhus. R. australis, the causative agent of Queensland tick typhus (QTT), is transmitted by certain Ixodes spp. ticks, which are predominantly present along the eastern coast of Australia [115]. Originally described as a mild, self-limiting illness, recent case reports demonstrated the occurrence of more severe forms with complications. R. australis shares many clinical features with rickettsialpox. Acute infections often begin with high-grade fever, headache, myalgias, and a maculopapular rash after a short incubation period averaging 5 days [116,117]. Infection has the potential to progress to severe sepsis with multiorgan failure, requiring prolonged hospitalization and admission to intensive care [118]. Since R. australis was first isolated in 1946, there has been one reported fatal QTT case [119]. Less common manifestations of QTT include splenomegaly, abdominal pain, renal failure, dry cough, and 
conjunctivitis [120]. Some reports documented confusion, seizures, and hallucinations as features of the disease [116].

Flea-borne spotted fever. Flea-borne spotted fever is caused by R. felis. It is transmitted to humans by fleas, in particular Ctenocephalides felis fleas. Patients often present with elevated fever, headache, and myalgia. A cutaneous rash is inconstant. Other manifestations may include abdominal pain, nausea, vomiting, cough, eschar, and photophobia. Rare cases of neurological involvement have been reported, notably, hearing loss and subacute meningitis $[121,122]$.

\section{Scrub typhus}

The genus Orientia contains two known species, O. tsutsugamushi and O. chuto [123], that cause scrub typhus, which is still regarded by some experts as a rickettsiosis, and are closely related to Rickettsia species [124,125]. Scrub typhus is a common cause of febrile illness in Asia. Fever and headache are the most common features of scrub typhus [126]. During World War 2, scrub typhus was a well-recognized cause of lethal meningitis in the Asia-Pacific region. Nowadays, only scarce data exist on the clinical burden of these pathogens in patients with CNS disease, e. g., in Laos and Thailand, where meningitis and meningoencephalitis occur as severe complications $[127,128]$. Isolated cases of acute encephalitis, abducens nerve palsy, and acute transverse myelitis due to O. tsutsugamushi were also recently described $[129,130]$.

\section{Rickettsia-related organisms}

Even though we have focused our review on members of the genus Rickettsia, we have searched the literature for CNS infection caused by the related organisms Ehrlichia and Anaplasma species.

Neurological involvement in human monocytic ehrlichiosis, caused by E. chaffeensis, is not rare [131-139]. Severe headache and symptoms of meningeal irritation are present in as many as 10\% of cases [140]. Most cases present as aseptic meningitis, but complications such as ataxia, cranial nerve paresis, meningoencephalitis, multiorgan failure, optic neuritis, seizures, and demyelinating polyneuropathy have been reported [137,138,141-143]. In addition, $E$. canis was detected in a child with aseptic meningitis [144].

A. phagocytophilum appears to be a rare agent of CNS infections [145], but cases of cerebral infarction or brachial plexopathy associated to A. phagocytophilum infection were reported $[146,147]$. In addition, $A$. phagocytophilum-infected neutrophils were described to enhance transmigration of Borrelia burgdorferi across the human blood-brain barrier in vitro [148].

\section{Conclusion}

Through a literature review, we identified 13 rickettsioses, including scrub typhus, causing CNS infections ranging from simple headache to lethal meningoencephalitis. In addition, surviving patients may suffer incapacitating sequellae. To date, the precise mechanisms of rickettsial pathogenesis for the CNS are only partially known, but animal models have demonstrated their pro-apototic effect for neurons. However, these bacteria are constantly susceptible to tetracyclines that may efficiently be used to cure patients. The remaining challenge is to integrate rickettsioses more systematically in the differential diagnosis of CNS infections. Without this effort, the diagnosis and treatment may be delayed, increasing the risk of severe forms. 


\section{Top five papers}

- Context: Parola P, Paddock CD, Socolovschi C, Labruna MB, Mediannikov O, Kernif T, Abdad MY, Stenos J, Bitam I, Fournier PE, and Raoult D (2013) Update on tickborne rickettsioses around the world: a geographic approach. Clin Microbiol Rev, 26, 657-702.

- Pathogenesis: Joshi SG and Kovacs AD (2007) Rickettsia rickettsii infection causes apoptotic death of cultured cerebellar granule neurons. J Med Microbiol, 56, 138-141.

- Epidemiology: Sexton DJ and Kirkland KB (1998). Rickettsial infections and the central nervous system. Clin Infect Dis,26, 247-248.

- Diseases: Bleck TP (1999) Central nervous system involvement in Rickettsial diseases. Neurol Clin, 17, 801-81.

- Diseases: Araki M, Takatsuka K, Kawamura J, and Kanno Y (2002) Japanese spotted fever involving the central nervous system: two case reports and a literature review. J Clin Microbiol, 40, 3874-3876.

\section{Key learning points}

- Rickettsioses are arthropod-transmitted and zoonotic diseases with a worldwide distribution.

- Rickettsioses represent a frequent threat for travelers to rural areas but are often misdiagnosed.

- Eleven of the currently diagnosed rickettsioses cause CNS infections in humans.

- Rickettsial CNS infections range from meningitis to lethal encephalomyelitis.

\section{References}

1. Rossati A, Bargiacchi O, Kroumova V, Garavelli PL [Vector transmitted diseases and climate changes in Europe]. Infez Med. 2014; 22:179-92. PMID: 25269959

2. Parola P, Paddock CD, Socolovschi C, Labruna MB, Mediannikov O, Kernif T, Abdad MY, Stenos J, Bitam I, Fournier PE, Raoult D. Update on tick-borne rickettsioses around the world: a geographic approach. Clin Microbiol Rev. 2013; 26:657-702. https://doi.org/10.1128/CMR.00032-13 PMID: 24092850

3. Walker DH, Fishbein DB. Epidemiology of rickettsial diseases. Eur J Epidemiol. 1991; 7:237-45. PMID: 1884775

4. Sahni SK, Narra HP, Sahni A, Walker DH. Recent molecular insights into rickettsial pathogenesis and immunity. Future Microbiol. 2013; 8:1265-1288. https://doi.org/10.2217/fmb.13.102 PMID: 24059918 
5. Eldin C, Parola P. Rickettsioses as causes of CNS infection in southeast Asia. Lancet Glob Health. 2015; 3:e67-e68. https://doi.org/10.1016/S2214-109X(14)70379-1 PMID: 25617194

6. Kularatne SAM, Fernando R, Selvaratnam S, Narampanawa C, Weerakoon K, Wickramasinghe S, Pathirage M, Weerasinghe V, Bandara A, Rajapakse J. Intra-aural tick bite causing unilateral facial nerve palsy in 29 cases over 16 years in Kandy, Sri Lanka: is rickettsial aetiology possible? BMC Infect Dis. 2018; 18:418. https://doi.org/10.1186/s12879-018-3338-8 PMID: 30134848

7. Boulahri T, Taous A, Berri MA, Traibi I, Elbenaye J, Rouimi A. [Rickettsiosis associated with cerebral infarction: a new case study]. Pan Afr Med J. 2017; 26:80. https://doi.org/10.11604/pamj.2017.26.80. 11434 PMID: 28491211

8. Kahloun R, Gargouri S, Abroug N, Sellami D, Ben YS, Feki J, Khairallah M. Visual loss associated with rickettsial disease. Ocul Immunol Inflamm. 2014; 22:373-8. https://doi.org/10.3109/09273948.2013. 848907 PMID: 24171650

9. Bohacsova M, Filipcik P, Opattova A, Valarikova J, Quevedo DM, Skultety L, Novak M, Sekeyova Z. Survival of rat cerebrocortical neurons after rickettsial infection. Microbes Infect. 2015; 17:845-9. https://doi.org/10.1016/j.micinf.2015.09.024 PMID: 26432946

10. Osterloh A, Papp S, Moderzynski K, Kuehl S, Richardt U, Fleischer B. Persisting Rickettsia typhi Causes Fatal Central Nervous System Inflammation. Infect Immun. 2016; 84:1615-32. https://doi. org/10.1128/IAI.00034-16 PMID: 26975992

11. Azad AF, Beard CB. Rickettsial pathogens and their arthropod vectors. Emerg Infect Dis. 1998; 4:179-86. PMID: 9621188

12. Raoult D, Woodward T, Dumler JS. The history of epidemic typhus. Infect Dis Clin North Am. 2004; 18:127-40. https://doi.org/10.1016/S0891-5520(03)00093-X PMID: 15081509

13. Azad AF. Pathogenic rickettsiae as bioterrorism agents. Clin Infect Dis. 2007; 45 Suppl 1:S52-S55. https://doi.org/10.1086/518147 PMID: 17582570

14. Walker DH, Valbuena GA, Olano JP. Pathogenic mechanisms of diseases caused by Rickettsia. Ann N Y Acad Sci. 2003; 990:1-11. https://doi.org/10.1111/j.1749-6632.2003.tb07331.x PMID: 12860594

15. Diop A, Raoult D, Fournier PE. Paradoxical evolution of rickettsial genomes. Ticks Tick Borne Dis. 2019; 10:462-9. https://doi.org/10.1016/j.ttbdis.2018.11.007 PMID: 30448253

16. Drevets DA, Leenen PJ, Greenfield RA. Invasion of the central nervous system by intracellular bacteria. Clin Microbiol Rev. 2004; 17:323-47. https://doi.org/10.1128/CMR.17.2.323-347.2004 PMID: 15084504

17. Abbott NJ, Patabendige AA, Dolman DE, Yusof SR, Begley DJ. Structure and function of the bloodbrain barrier. Neurobiol Dis. 2010; 37:13-25. https://doi.org/10.1016/j.nbd.2009.07.030 PMID: 19664713

18. Barichello T, Fagundes GD, Generoso JS, Elias SG, Simoes LR, Teixeira AL. Pathophysiology of neonatal acute bacterial meningitis. J Med Microbiol. 2013; 62:1781-9. https://doi.org/10.1099/jmm.0. 059840-0 PMID: 23946474

19. Kim KS. Mechanisms of microbial traversal of the blood-brain barrier. Nat Rev Microbiol. 2008; 6:625-34. https://doi.org/10.1038/nrmicro1952 PMID: 18604221

20. Rolain JM, Maurin M, Vestris G, Raoult D. In vitro susceptibilities of 27 rickettsiae to 13 antimicrobials. Antimicrob Agents Chemother. 1998; 42:1537-41. PMID: 9660979

21. Rolain JM, Sthul L, Maurin M, Raoult D. Evaluation of antibiotic susceptibilities of three Rickettsial species including Rickettsia felis by a quantitative PCR DNA assay. Antimicrob Agents Chemother. 2002; 46:2747-51. https://doi.org/10.1128/AAC.46.9.2747-2751.2002 PMID: 12183224

22. Cascio A, Colomba C, Di RD, Salsa L, di ML, Titone L. Efficacy and safety of clarithromycin as treatment for Mediterranean spotted fever in children: a randomized controlled trial. Clin Infect Dis. 2001; 33:409-11. https://doi.org/10.1086/321864 PMID: 11438914

23. Colomba C, Saporito L, Polara VF, Rubino R, Titone L. Mediterranean spotted fever: clinical and laboratory characteristics of 415 Sicilian children. BMC Infect Dis. 2006; 6:60. https://doi.org/10.1186/ 1471-2334-6-60 PMID: 16553943

24. Bradshaw MJ, Venkatesan A. Emergency Evaluation and Management of Encephalitis and Myelitis in Adults. Semin Neurol. 2019; 39:82-101. https://doi.org/10.1055/s-0038-1676845 PMID: 30743295

25. Bradshaw MJ, Lalor KB, Vu N, Pruthi S, Bloch KC. Child Neurology: Rocky Mountain spotted fever encephalitis. Neurology. 2017; 88:e92-e95. https://doi.org/10.1212/WNL.0000000000003722 PMID: 28289173

26. Horney LF, Walker DH. Meningoencephalitis as a major manifestation of Rocky Mountain spotted fever. South Med J. 1988; 81:915-8. https://doi.org/10.1097/00007611-198807000-00028 PMID: 3393952 
27. Walker $\mathrm{DH}$, Raoult $\mathrm{D}$. Rickettsia rickettsii and other spotted fever group rickettsiae (Rocky Mountain spotted fever and other spotted fever. In: Mandell, Douglas, Benett, eds. Principles and practice of infectious diseases. 2000; 2:2035-45. Churchill Livingstone, New York.

28. Walker DH, Raoult D, Dumler J S, Marrie T. Rickettsial diseases. In: Braunwald, Fauci, Kasper, Hauser, Longo, Jameson, eds. Harrison's Principles of Internal medicine. 2001; 1:1056-73. McGraw-Hill Professional, New york.

29. Miller JR, Jubelt B. Bacterial infections. In: Rowland, ed. Merritt's Textbook of Neurology ( 10th edn). 2018;125-7. lippincott, Williams \& Wilkins, Philadelphia.

30. Helmick CG, Bernard KW, D’Angelo LJ. Rocky Mountain spotted fever: clinical, laboratory, and epidemiological features of 262 cases. J Infect Dis. 1984; 150:480-8. https://doi.org/10.1093/infdis/150.4. 480 PMID: 6491365

31. Kulkarni A. Childhood rickettsiosis. Indian J Pediatr. 2011; 78:81-7. https://doi.org/10.1007/s12098010-0255-2 PMID: 20967515

32. Baganz MD, Dross PE, Reinhardt JA. Rocky Mountain spotted fever encephalitis: MR findings. AJNR Am J Neuroradiol. 1995; 16:919-22. PMID: 7611074

33. Massey EW, Thames T, Coffey CE, Gallis HA. Neurologic complications of Rocky Mountain spotted fever. South Med J. 1985; 78:1288-90, 1303. https://doi.org/10.1097/00007611-198511000-00004 PMID: 4071134

34. Steinfeld HJ, Silverstein J, Weisburger W, Rattner F. Deafness associated with Rocky Mountain spotted fever. Md Med J. 1988; 37:287-8. PMID: 3367718

35. Kirk JL, Fine DP, Sexton DJ, Muchmore HG. Rocky Mountain spotted fever. A clinical review based on 48 confirmed cases, 1943-1986. Medicine (Baltimore). 1990; 69:35-45.

36. Archibald LK, Sexton DJ. Long-term sequelae of Rocky Mountain spotted fever. Clin Infect Dis. 1995; 20:1122-5. https://doi.org/10.1093/clinids/20.5.1122 PMID: 7619986

37. Sexton DJ, Kirkland KB. Rickettsial infections and the central nervous system. Clin Infect Dis. 1998; 26:247-8. https://doi.org/10.1086/517043 PMID: 9455578

38. Walker DH. Rickettsial and chlamydial disease. In: Kissane, ed. Anderson's Pathology. 1990; 348-60. CV Mosby, St Louis.

39. Pai H, Sohn S, Seong Y, Kee S, Chang WH, Choe KW. Central nervous system involvement in patients with scrub typhus. Clin Infect Dis. 1997; 24:436-40. https://doi.org/10.1093/clinids/24.3.436 PMID: 9114196

40. Joshi SG, Kovacs AD. Rickettsia rickettsii infection causes apoptotic death of cultured cerebellar granule neurons. J Med Microbiol. 2007; 56:138-41. https://doi.org/10.1099/jmm.0.46826-0 PMID: 17172530

41. Bleck TP. Central nervous system involvement in Rickettsial diseases. Neurol Clin. 1999; 17:801-12. PMID: 10517929

42. Cowan G. Rickettsial diseases: the typhus group of fevers—a review. Postgrad Med J. 2000; 76:26972. https://doi.org/10.1136/pmj.76.895.269 PMID: 10775278

43. Rydkina E, Sahni SK, Santucci LA, Turpin LC, Baggs RB, Silverman DJ. Selective modulation of antioxidant enzyme activities in host tissues during Rickettsia conorii infection. Microb Pathog. 2004; 36:293-301. https://doi.org/10.1016/j.micpath.2004.01.002 PMID: 15120155

44. Raoult D, Weiller PJ, Chagnon $A$, Chaudet $H$, Gallais $H$, Casanova P. Mediterranean spotted fever: clinical, laboratory and epidemiological features of 199 cases. Am J Trop Med Hyg. 1986; 35:845-50. https://doi.org/10.4269/ajtmh.1986.35.845 PMID: 3728799

45. Walker DH, Herrero-Herrero JI, Ruiz-Beltran R, Bullon-Sopelana A, Ramos-Hidalgo A. The pathology of fatal Mediterranean spotted fever. Am J Clin Pathol. 1987; 87:669-72. https://doi.org/10.1093/ajcp/ 87.5.669 PMID: 3578143

46. Font CB, Espejo AE, Munoz ET, Uriz US, Bella CF, Segura PF. [Mediterranean boutonneuse fever. Study of 246 cases]. Med Clin (Barc). 1991; 96:121-5.

47. Dolado MA, Portocarrero SJ, Madridejo JR, Navarror PJC, Urra GD. Meningoencephalitis due to Rickettsia conorii. Etiopathological, clinical and diagnostic aspects. Neurologia. 1994; 9:72-5. PMID: 8204253

48. Duque V, Ventura C, Seixas D, Barai A, Mendonca N, Martins J, da Cunha S, Melico-Silvestre A. Mediterranean spotted fever and encephalitis: a case report and review of the literature. J Infect Chemother. 2012; 18:105-8. https://doi.org/10.1007/s10156-011-0295-1 PMID: 21879306

49. Amaro M, Bacellar F, Franca A. Report of eight cases of fatal and severe Mediterranean spotted fever in Portugal. Ann N Y Acad Sci. 2003; 990:331-43. https://doi.org/10.1111/j.1749-6632.2003.tb07384.x PMID: 12860647 
50. Ezpeleta D, Munoz-Blanco JL, Tabernero C, Gimenez-Roldan S. [Neurological complications of Mediterranean boutonneuse fever. Presentation of a case of acute encephalomeningomyelitis and review of the literature]. Neurologia. 1999; 14:38-42. PMID: 10079692

51. Tzavella K, Chatzizisis YS, Vakali A, Mandraveli K, Zioutas D, Alexiou-Daniel S. Severe case of Mediterranean spotted fever in Greece with predominantly neurological features. J Med Microbiol. 2006; 55:341-3. https://doi.org/10.1099/jmm.0.46337-0 PMID: 16476800

52. Texier $P$, Rousselot JM, Quillerou $D$, Aufrant $C$, Robain D, Foucaud P. [Mediterranean boutonneuse fever. Apropos of a fatal case in a newborn infant]. Arch Fr Pediatr. 1984; 41:51-3. PMID: 6721652

53. Benhammou B, Balafrej A, Mikou N. [Mediterranean boutonneuse fever disclosed by severe neurological involvement]. Arch Fr Pediatr. 1991; 48:635-6. PMID: 1763933

54. De Klippel N, De Keyser J, Merckx H, Ebinger G. Meningoencephalitis caused by Rickettsia conorii. Clin Neurol Neurosurg. 1991; 93:345-7. PMID: 1665772

55. Tikare NV, Shahapur PR, Bidari LH, Mantur BG. Rickettsial meningoencephalitis in a child-a case report. J Trop Pediatr. 2010; 56:198-200. https://doi.org/10.1093/tropej/fmp065 PMID: 19667037

56. Bougteba A, Basir A, Charradi N. [Meningoencephalitis caused by Rickettsia conorii in a young infant]. Rev Neurol (Paris). 2011; 167:173-6. PMID: 20797742

57. Aliaga L, Sanchez-Blazquez P, Rodriguez-Granger J, Sampedro A, Orozco M, Pastor J. Mediterranean spotted fever with encephalitis. J Med Microbiol. 2009; 58:521-5. https://doi.org/10.1099/jmm.0. 004465-0 PMID: 19273650

58. Mahara F, Koga K, Sawada S, Taniguchi T, Shigemi F, Suto T, Tsuboi Y, Ooya A, Koyama H, Uchiyama T. [The first report of the rickettsial infections of spotted fever group in Japan: three clinical cases]. Kansenshogaku Zasshi. 1985; 59:1165-71. PMID: 3938467

59. Kodama K, Noguchi T, Chikahira Y. [Japanese spotted fever complicated by acute respiratory failure]. Kansenshogaku Zasshi. 2000; 74:162-5. PMID: 10741008

60. Kodama K, Senba T, Yamauchi H, Chikahira Y, Fujita H. Japanese spotted fever associated with multiorgan failure. J Infect Chemother. 2001; 7:247-250. PMID: 11810592

61. Honda E, Tanioka M, Honda T, et al. Nine cases of Japanese spotted fever, including 3 cases with DIC and MOF treated at ICU. Rinsho Hihu. 2003; 57:523-6.

62. Iwamoto K, Nishimura F, Yoshino Y, Mihara J, Okabe T, Kameda H, Kubagawa T. [A case of spotted fever with central nervous system involvement]. Kansenshogaku Zasshi. 1988; 62:1192-6. PMID: 3148016

63. Kodama K, Senba T, Yamauchi H, Chikahira Y, Fujita H. A patient with Japanese spotted fever complicated by meningoencephalitis. Kansenshogaku Zasshi. 2001; 75:812-4. PMID: 11605191

64. Araki M, Takatsuka K, Kawamura J, Kanno Y. Japanese spotted fever involving the central nervous system: two case reports and a literature review. J Clin Microbiol 2002; 40:3874-6. https://doi.org/10. 1128/JCM.40.10.3874-3876.2002 PMID: 12354906

65. Kodama K, Senba T, Yamauchi H, Chikahira Y, Katayama T, Furuya Y, Fujita H, Yamamoto S. Fulminant Japanese spotted fever definitively diagnosed by the polymerase chain reaction method. $\mathrm{J}$ Infect Chemother. 2002; 8:266-8. https://doi.org/10.1007/s10156-002-0185-7 PMID: 12373493

66. Nakata R, Motomura M, Tokuda M, Nakajima H, Masuda T, Fukuda T, Tsujino A, Yoshimura T, Kawakami A. A case of Japanese spotted fever complicated with central nervous system involvement and multiple organ failure. Intern Med. 2012; 51:783-6. https://doi.org/10.2169/internalmedicine.51.6214 PMID: 22466839

67. Lakos A. Tick-borne lymphadenopathy-a new rickettsial disease? Lancet. 1997; 350:1006. https:// doi.org/10.1016/S0140-6736(05)64072-X PMID: 9329524

68. Lakos A. Tick-borne lymphadenopathy (TIBOLA). Wien Klin Wochenschr. 2002; 114:648-54. PMID: 12422619

69. Lakos A, Korosi A, Foldvari G. Contact with horses is a risk factor for tick-borne lymphadenopathy (TIBOLA): a case control study. Wien Klin Wochenschr. 2012; 124:611-7. https://doi.org/10.1007/ s00508-012-0217-y PMID: 22878792

70. Raoult $D$, Roux V. Rickettsioses as paradigms of new or emerging infectious diseases. Clin Microbiol Rev. 1997; 10:694-719. PMID: 9336669

71. Oteo JA, Ibarra V, Blanco JR, Martinez dA V, Marquez FJ, Portillo A, Raoult D, Anda P. Dermacentorborne necrosis erythema and lymphadenopathy: clinical and epidemiological features of a new tickborne disease. Clin Microbiol Infect. 2004; 10:327-31. https://doi.org/10.1111/j.1198-743X.2004. 00782.x PMID: 15059122 
72. Ibarra V, Oteo JA, Portillo A, Santibanez S, Blanco JR, Metola L, Eiros JM, Perez-Martinez L, Sanz M. Rickettsia slovaca infection: DEBONEL/TIBOLA. Ann N Y Acad Sci. 2006; 1078:206-14. https://doi. org/10.1196/annals.1374.040 PMID: 17114711

73. Selmi M, Bertolotti L, Tomassone L, Mannelli A. Rickettsia slovaca in Dermacentor marginatus and tick-borne lymphadenopathy, Tuscany, Italy. Emerg Infect Dis. 2008; 14:817-20. https://doi.org/10. 3201/eid1405.070976 PMID: 18439371

74. Angelakis E, Pulcini C, Waton J, Imbert P, Socolovschi C, Edouard S, Dellamonica P, Raoult D. Scalp eschar and neck lymphadenopathy caused by Bartonella henselae after Tick Bite. Clin Infect Dis. 2010; 50:549-51. https://doi.org/10.1086/650172 PMID: 20070235

75. Brezina R, Rehacek J, Ac P, Majerska M. Two strains of rickettsiae of Rocky Mountain spotted fever group recovered from Dermacentor marginatus ticks in Czechoslovakia. Results of preliminary serological identification. Acta Virol. 1969; 13:142-5. PMID: 4389040

76. Raoult D, Berbis $\mathrm{P}$, Roux V, Xu W, Maurin M. A new tick-transmitted disease due to Rickettsia slovaca Lancet. 1997; 350:112-3. https://doi.org/10.1016/S0140-6736(05)61814-4

77. Oteo JA, Portillo A. Tick-borne rickettsioses in Europe. Ticks Tick Borne Dis. 2012; 3:271-8. https:// doi.org/10.1016/j.ttbdis.2012.10.035 PMID: 23177355

78. Raoult D, Lakos A, Fenollar F, Beytout J, Brouqui P, Fournier PE. Spotless rickettsiosis caused by Rickettsia slovaca and associated with Dermacentor ticks. Clin Infect Dis. 2002; 34:1331-6. https:// doi.org/10.1086/340100 PMID: 11981728

79. Rieg S, Schmoldt S, Theilacker C, de WK, Wolfel S, Kern WV, Dobler G. Tick-borne lymphadenopathy (TIBOLA) acquired in Southwestern Germany. BMC Infect Dis. 2011; 11:167. https://doi.org/10.1186/ 1471-2334-11-167 PMID: 21663601

80. Mittermayer T, Brezina R, Urvolgyi J. First report of an infection with Rickettsia slovaca. Folia Parasitol (Praha). 1980; 27:373-6.

81. Cazorla C, Enea M, Lucht F, Raoult D. First isolation of Rickettsia slovaca from a patient, France. Emerg Infect Dis. 2003; 9:135. https://doi.org/10.3201/eid0901.020192 PMID: 12533298

82. Ibarra V, Portillo A, Santibanez S, Blanco JR, Perez-Martinez L, Marquez J, Oteo JA. DEBONEL TIBOLA: is Rickettsia slovaca the only etiological agent? Ann N Y Acad Sci. 2005; 1063:346-8. https://doi.org/10.1196/annals.1355.056 PMID: 16481539

83. Mediannikov O, Matsumoto K, Samoylenko I, Drancourt M, Roux V, Rydkina E, Davoust B, Tarasevich I, Brouqui P, Fournier PE. Rickettsia raoultii sp. nov., a spotted fever group rickettsia associated with Dermacentor ticks in Europe and Russia. Int J Syst Evol Microbiol. 2008; 58:1635-9. https://doi. org/10.1099/ijs.0.64952-0 PMID: 18599708

84. Parola P, Rovery C, Rolain JM, Brouqui P, Davoust B, Raoult D. Rickettsia slovaca and R. raoultii in tick-borne Rickettsioses. Emerg Infect Dis. 2009; 15:1105-8. https://doi.org/10.3201/eid1507.081449 PMID: 19624931

85. Harrison N, Burgmann H, Forstner C, Ramharter M, Szell M, Schotta AM, Stanek G, Markowicz M. Molecular diagnosis of African tick bite fever using eschar swabs in a traveller returning from Tanzania. Wien Klin Wochenschr. 2016; 128:602-5. https://doi.org/10.1007/s00508-016-1047-0 PMID: 27488618

86. Zammarchi L, Farese A, Trotta M, Amantini A, Raoult D, Bartoloni A. Rickettsia africae infection complicated with painful sacral syndrome in an Italian traveller returning from Zimbabwe. Int J Infect Dis. 2014; 29:194-6. https://doi.org/10.1016/j.jij.2014.10.017 PMID: 25447725

87. Fujisawa T, Kadosaka T, Fujita H, Ando S, Takano A, Ogasawara Y, Kawabata H, Seishima M. Rickettsia africae infection in a Japanese traveller with many tick bites. Acta Derm Venereol. 2012; 92:443-4. https://doi.org/10.2340/00015555-1313 PMID: 22277948

88. Jensenius M, Fournier PE, Fladby T, Hellum KB, Hagen T, Prio T, Christiansen MS, Vene S, Raoult D, Myrvang B. Sub-acute neuropathy in patients with African tick bite fever. Scand J Infect Dis.2006; 38:114-8. https://doi.org/10.1080/00365540500321579 PMID: 16449002

89. Burgdorfer W, Aeschlimann A, Peter O, Hayes SF, Philip RN. Ixodes ricinus: vector of a hitherto undescribed spotted fever group agent in Switzerland. Acta Trop0. 1979; 36:357-67.

90. Beati L, Peter O, Burgdorfer W, Aeschlimann A, Raoult D. Confirmation that Rickettsia helvetica sp. nov. is a distinct species of the spotted fever group of rickettsiae. Int J Syst Bacteriol. 1993; 43:521-6. https://doi.org/10.1099/00207713-43-3-521 PMID: 8102245

91. Fournier PE, Grunnenberger F, Jaulhac B, Gastinger G, Raoult D. Evidence of Rickettsia helvetica infection in humans, eastern France. Emerg Infect Dis. 2000; 6:389-92. PMID: 10905974

92. Nilsson K, Lindquist $\mathrm{O}$, Pahlson $\mathrm{C}$. Association of Rickettsia helvetica with chronic perimyocarditis in sudden cardiac death. Lancet. 1999; 354:1169-73. https://doi.org/10.1016/S0140-6736(99)04093-3 PMID: 10513711 
93. Baumann D, Pusterla N, Peter O, Grimm F, Fournier PE, Schar G, Bossart W, Lutz H, Weber R. [Fever after a tick bite: clinical manifestations and diagnosis of acute tick bite-associated infections in northeastern Switzerland]. Dtsch Med Wochenschr. 2003; 128:1042-7. PMID: 12736854

94. Fournier PE, Allombert C, Supputamongkol Y, Caruso G, Brouqui P, Raoult D. Aneruptive fever associated with antibodies to Rickettsia helvetica in Europe and Thailand. J Clin Microbiol. 2004; 42:8168. https://doi.org/10.1128/JCM.42.2.816-818.2004 PMID: 14766859

95. Nilsson K. Septicaemia with Rickettsia helvetica in a patient with acute febrile illness, rash and myasthenia. J Infect. 2009; 58:79-82. https://doi.org/10.1016/j.jinf.2008.06.005 PMID: 18649945

96. Nilsson K, Wallmenius K, Pahlson C. Coinfection with Rickettsia helvetica and Herpes Simplex Virus 2 in a Young Woman with Meningoencephalitis. Case Rep Infect Dis. 2011: 469194. https://doi.org/10. 1155/2011/469194 PMID: 22567472

97. Nilsson K, Elfving K, Pahlson C. Rickettsia helvetica in patient with meningitis, Sweden, 2006. Emerg Infect Dis. 2010; 16:490-2. https://doi.org/10.3201/eid1603.090184 PMID: 20202426

98. Marrie TJ, Raoult D. Rickettsial infections of the central nervous system. Semin Neurol. 1992; 12:213-24. https://doi.org/10.1055/s-2008-1041178 PMID: 1455109

99. Pether JV, Jones W, Lloyd G, Rutter DA, Barry M. Fatal murine typhus from Spain. Lancet. 1994; 344:897-8.

100. Allen A C, Saitz S. A comparative study of the pathology of scrub tyohus (Tsutsugamushi disease) and other rickettsial diseases. Am J Pathol. 1945; 21:681.

101. Bitsori M, Galanakis E, Gikas A, Scoulica E, Sbyrakis S. Rickettsia typhi infection in childhood. Acta Paediatr. 2002; 91:59-61. PMID: 11883820

102. Silpapojakul K, Ukkachoke $C$, Krisanapan S, Silpapojakul K. Rickettsial meningitis and encephalitis. Arch Intern Med. 1991; 151: 1753-7. PMID: 1888241

103. Gelston AL, Jones TC. Typhus fever: report of an epidemic in New York City in 1847. J Infect Dis. 1977; 136:813-21. https://doi.org/10.1093/infdis/136.6.813 PMID: 336803

104. Galanakis E, Gikas A, Bitsori M, Sbyrakis S. Rickettsia typhi infection presenting as subacute meningitis. J Child Neurol. 2002; 17:156-7. https://doi.org/10.1177/088307380201700217 PMID: 11952082

105. Dumler JS, Taylor JP, Walker DH. Clinical and laboratory features of murine typhus in south Texas, 1980 through 1987. JAMA. 1991; 266:1365-70. PMID: 1880866

106. Moy WL, Ooi ST. Abducens nerve palsy and meningitis by Rickettsia typhi. Am J Trop Med Hyg. 2015; 92:620-4. https://doi.org/10.4269/ajtmh.14-0559 PMID: 25548377

107. Huebner RJ, Stamps $\mathrm{P}$, Armstrong $\mathrm{C}$. Rickettsialpox; a newly recognized rickettsial disease; isolation of the etiological agent. Public Health Rep. 1946; 61:1605-14.

108. Brouqui $P$, Parola $P$, Fournier PE, Raoult D. Spotted fever rickettsioses in southern and eastern Europe. FEMS Immunol Med Microbiol. 2007; 49:2-12. https://doi.org/10.1111/j.1574-695X.2006 00138.x PMID: 17266709

109. Brettman LR, Lewin S, Holzman RS, Goldman WD, Marr JS, Kechijian P, Schinella R. Rickettsialpox: report of an outbreak and a contemporary review. Medicine (Baltimore). 1981; 60:363-72.

110. Kass EM, Szaniawski WK, Levy H, Leach J, Srinivasan K, Rives C. Rickettsialpox in a New York City hospital, 1980 to 1989. N Engl J Med. 1994; 331:1612-7. https://doi.org/10.1056/ NEJM199412153312403 PMID: 7969341

111. Eremeeva M, Balayeva N, Ignatovich V, Raoult D. Genomic study of Rickettsia akari by pulsed-field gel electrophoresis. J Clin Microbiol. 1995; 33:3022-4. PMID: 8576365

112. Radulovic S, Feng HM, Morovic M, Djelalija B, Popov V, Crocquet-Valdes $\mathrm{P}$, Walker DH. Isolation of Rickettsia akari from a patient in a region where Mediterranean spotted fever is endemic. Clin Infect Dis. 1996; 22:216-20. https://doi.org/10.1093/clinids/22.2.216 PMID: 8838175

113. Renvoise A, van't Wout JW, van der Schroeff JG, Beersma MF, Raoult D. A case of rickettsialpox in Northern Europe. Int J Infect Dis. 2012; 16:e221-e222. https://doi.org/10.1016/j.ijid.2011.11.009 PMID: 22257655

114. Raoult $D$, Roux V. Rickettsioses as paradigms of new or emerging infectious diseases. Clin Microbio Rev. 1997; 10:694-719. PMID: 9336669

115. Barker SC, Walker AR. Ticks of Australia. The species that infest domestic animals and humans. Zootaxa. 2014; 1-144.

116. Sexton DJ, Dwyer B, Kemp R, Graves S. Spotted fever group rickettsial infections in Australia. Rev Infect Dis. 1991; 13:876-86. PMID: 1962102 
117. Stewart A, Armstrong M, Graves S, Hajkowicz K. Rickettsia australis and Queensland Tick Typhus: A Rickettsial Spotted Fever Group Infection in Australia. Am J Trop Med Hyg. 2017; 97:24-9. https:// doi.org/10.4269/ajtmh.16-0915 PMID: 28719297

118. Stewart A, Armstrong M, Graves S, Hajkowicz K. Clinical Manifestations and Outcomes of Rickettsia australis Infection: A 15-Year Retrospective Study of Hospitalized Patients. Trop Med Infect Dis. 2017; 2(2).

119. Sexton DJ, King G, Dwyer B. Fatal Queensland tick typhus. J Infect Dis. 1990; 162:779-780. https:// doi.org/10.1093/infdis/162.3.779 PMID: 2388005

120. McBride WJ, Hanson JP, Miller R, Wenck D. Severe spotted fever group rickettsiosis, Australia Emerg Infect Dis. 2007; 13:1742-4. https://doi.org/10.3201/eid1311.070099 PMID: 18217560

121. Renvoise A, Joliot AY, Raoult D. Rickettsia felis infection in man, France. Emerg Infect Dis. 2009; 15:1126-7. https://doi.org/10.3201/eid1507.090029 PMID: 19624937

122. Lindblom A, Severinson $K$, Nilsson K. Rickettsia felis infection in Sweden: report of two cases with subacute meningitis and review of the literature. Scand J Infect Dis. 2010; 42:906-9. https://doi.org/10. 3109/00365548.2010.508466 PMID: 20735330

123. Izzard L, Fuller A, Blacksell SD, Paris DH, Richards AL, Aukkanit N, Nguyen C, Jiang J, Fenwick S, Day NP, Graves S, Stenos J. Isolation of a novel Orientia species (O. chuto sp. nov.) from a patient infected in Dubai. J Clin Microbiol. 2010; 48:4404-9. https://doi.org/10.1128/JCM.01526-10 PMID: 20926708

124. Tamura A, Ohashi N, Urakami H, Miyamura S. Classification of Rickettsia tsutsugamushi in a new genus, Orientia gen. nov., as Orientia tsutsugamushi comb. nov. Int J Syst Bacteriol. 1995; 45:58991. https://doi.org/10.1099/00207713-45-3-589 PMID: 8590688

125. Tshokey T, Stenos J, Durrheim DN, Eastwood K, Nguyen C, Vincent G, Graves SR. Rickettsial Infections and Q Fever Amongst Febrile Patients in Bhutan. Trop Med Infect Dis. 2018; 3(1).

126. Jamil M, Lyngrah KG, Lyngdoh M, Hussain M. Clinical Manifestations and Complications of Scrub Typhus: A Hospital Based Study from North Eastern India. J Assoc Physicians India. 2014; 62:19-23.

127. Dittrich S, Rattanavong S, Lee SJ, Panyanivong P, Craig SB, Tulsiani SM, Blacksell SD, Dance DA, Dubot-Peres A, Sengduangphachanh A, Phoumin P, Paris DH, Newton PN. Orientia, rickettsia, and leptospira pathogens as causes of CNS infections in Laos: a prospective study. Lancet Glob Health. 2015; 3:e104-e112. https://doi.org/10.1016/S2214-109X(14)70289-X PMID: 25617190

128. Olsen SJ, Campbell AP, Supawat $K$, Liamsuwan $S$, Chotpitayasunondh $T$, Laptikulthum $S$, Viriyavejakul A, Tantirittisak T, Tunlayadechanont S, Visudtibhan A, Vasiknanonte P, Janjindamai S, Boonluksiri P, Rajborirug K, Watanaveeradej V, Khetsuriani N, Dowell SF. Infectious causes of encephalitis and meningoencephalitis in Thailand, 2003-2005. Emerg Infect Dis. 2015; 21:280-9. https://doi.org/10. 3201/eid2102.140291 PMID: 25627940

129. Mittal M, Thangaraj JWV, Rose W, Verghese VP, Kumar CPG, Mittal M, Sabarinathan R, Bondre V, Gupta N, Murhekar MV. Scrub Typhus as a Cause of Acute Encephalitis Syndrome, Gorakhpur, Uttar Pradesh, India. Emerg Infect Dis. 2017; 23:1414-6. https://doi.org/10.3201/eid2308.170025 PMID: 28726617

130. Dinesh KN, Arun BT, Vijayadevagaran V, Ananthakrishnan S, Kittu D. Clinical Profile of Scrub Typhus Meningoencephalitis among South Indian Children. J Trop Pediatr. 2018; 64:472-8. https://doi.org/ 10.1093/tropej/fmx096 PMID: 29272545

131. Grant AC, Hunter S, Partin WC. A case of acute monocytic ehrlichiosis with prominent neurologic signs. Neurology. 1997; 48:1619-23. https://doi.org/10.1212/wnl.48.6.1619 PMID: 9191777

132. Berry DS, Miller RS, Hooke JA, Massung RF, Bennett J, Ottolini MG. Ehrlichial meningitis with cerebrospinal fluid morulae. Pediatr Infect Dis J. 1999; 18(6):552-5. PMID: 10391189

133. Lee YH, Yun YJ, Jeong SH. Isolated abducens nerve palsy in a patient with scrub typhus. J AAPOS. 2010; 14:460-1. https://doi.org/10.1016/j.jaapos.2010.06.016 PMID: 21035078

134. Yun JS, Song JS, Choi EJ, Hwang JH, Lee CS, Park EH. Successfully Managed Acute Transverse Myelitis Related to Scrub Typhus and Serial Image Findings. Am J Trop Med Hyg. 2017; 96:557-60. https://doi.org/10.4269/ajtmh.16-0524 PMID: 28115665

135. Marty AM, Dumler JS, Imes G, Brusman HP, Smrkovski LL, Frisman DM. Ehrlichiosis mimicking thrombotic thrombocytopenic purpura. Case report and pathological correlation. Hum Pathol. 1995; 26:920-5. https://doi.org/10.1016/0046-8177(95)90017-9 PMID: 7635455

136. Eng TR, Harkess JR, Fishbein DB, Dawson JE, Greene CN, Redus MA, Satalowich FT. Epidemiologic, clinical, and laboratory findings of human ehrlichiosis in the United States, 1988. JAMA. 1990; 264: 2251-8. PMID: 2214103

137. Harkess JR, Stucky D, Ewing SA. Neurologic abnormalities in a patient with human ehrlichiosis. South Med J. 1990; 83:1341-3. https://doi.org/10.1097/00007611-199011000-00031 PMID: 2237570 
138. Ratnasamy N, Everett ED, Roland WE, McDonald G, Caldwell CW. Central nervous system manifestations of human ehrlichiosis. Clin Infect Dis. 1996; 23:314-9. https://doi.org/10.1093/clinids/23.2.314 PMID: 8842270

139. Dredla B, Freeman WD. Ehrlichia Meningitis Mimicking Aneurysmal Subarachnoid Hemorrhage: A Case Study for Medical Decision-Making Heuristics. Neurohospitalist. 2016; 6:76-9. https://doi.org/ 10.1177/1941874415596743 PMID: 27053985

140. Davis LE, Paddock CD, Childs JE. Ehrlichiosis and the nervous system. In: Davis Kennedy, eds. Infectious diseases of the nervous system. 2000; 499-520. Butterworth-Heinemann, Oxford.

141. Carter N, Miller NR Fourth nerve palsy caused by Ehrlichia chaffeensis. J Neuroophthalmol. 1997; 17:47-50. PMID: 9093962

142. Buzzard SL, Bissell BD, Thompson Bastin ML. Ehrlichiosis presenting as severe sepsis and meningoencephalitis in an immunocompetent adult. JMM Case Rep. 2018; 5:e005162. https://doi.org/10. 1099/jmmcr.0.005162 PMID: 30425837

143. Lee MS, Goslee TE, Lessell S. Ehrlichiosis optic neuritis. Am J Ophthalmol. 2003; 135:412-3. https:// doi.org/10.1016/s0002-9394(02)01945-1 PMID: 12614774

144. Golden SE. Aseptic meningitis associated with Ehrlichia canis infection. Pediatr Infect Dis J. 1989; 8:335-7. PMID: 2726324

145. Bakken JS, Krueth J, Wilson-Nordskog C, Tilden RL, Asanovich K, Dumler JS. Clinical and laboratory characteristics of human granulocytic ehrlichiosis. JAMA. 1996; 275:199-205. PMID: 8604172

146. Horowitz HW, Marks SJ, Weintraub M, Dumler JS. Brachial plexopathy associated with human granulocytic ehrlichiosis. Neurology. 1996; 46:1026-9. https://doi.org/10.1212/wnl.46.4.1026 PMID: 8780084

147. Kim SW, Kim CM, Kim DM, Yun NR. Manifestation of anaplasmosis as cerebral infarction: a case report. BMC Infect Dis. 2018; 18:409. https://doi.org/10.1186/s12879-018-3321-4 PMID: 30119642

148. Nyarko E, Grab DJ, Dumler JS. Anaplasma phagocytophilum-infected neutrophils enhance transmigration of Borrelia burgdorferi across the human blood brain barrier in vitro. Int J Parasitol. 2006; 36:601-5. https://doi.org/10.1016/j.ijpara.2006.01.014 PMID: 16600247

149. Heglasova I, Vichova B, Kraljik J, Mosansky L, Miklisova D, Stanko M. Molecular evidence and diversity of the spotted-fever group Rickettsia spp. in small mammals from natural, suburban and urban areas of Eastern Slovakia. Ticks Tick Borne. 2018; Dis 9: 1400-6. https://doi.org/10.1016/j.ttbdis. 2018.06.011 PMID: 30207272

150. Lieskovska N, Minichova L, Sorf R, Gacikova E, Vrbova E, Kazimirova M, Sekeyova Z. Dogs as sentinels for distribution of spotted-fever group rickettsiae in Slovakia. Travel Med Infect Dis. 2018; 26:645. https://doi.org/10.1016/j.tmaid.2018.05.011 PMID: 29800723

151. Toledo RS, Tamekuni K, Filho MF, Haydu VB, Barbieri AR, Hiltel AC, Pacheco RC, Labruna MB, Dumler JS, Vidotto O. Infection by spotted fever rickettsiae in people, dogs, horses and ticks in Londrina, Parana State, Brazil. Zoonoses Public Health. 2011; 58:416-23. https://doi.org/10.1111/j.1863-2378. 2010.01382.x PMID: 21824336

152. Hornok S, Sugar L, Fernandez de Mera IG, de la Fuente J, Horvath G, Kovacs T, Micsutka A, Gonczi E, Flaisz B, Takacs N, Farkas R, Meli ML, Hofmann-Lehmann R. Tick- and fly-borne bacteria in ungulates: the prevalence of Anaplasma phagocytophilum, haemoplasmas and rickettsiae in water buffalo and deer species in Central Europe, Hungary. BMC Vet Res. 2018; 14:98. https://doi.org/10.1186/ s12917-018-1403-6 PMID: 29554900

153. Eremeeva ME, Weiner LM, Zambrano ML, Dasch GA, Hu R, Vilcins I, Castro MB, Bonilla DL, Padgett KA. Detection and characterization of a novel spotted fever group Rickettsia genotype in Haemaphysalis leporispalustris from California, USA. Ticks Tick Borne Dis. 2018; 9:814-8. https://doi.org/10. 1016/j.ttbdis.2018.02.023 PMID: 29545107

154. Klitgaard K, Hojgaard J, Isbrand A, Madsen JJ, Thorup K, Bodker R. Screening for multiple tick-borne pathogens in Ixodes ricinus ticks from birds in Denmark during spring and autumn migration seasons. Ticks Tick Borne Dis. 2019; 10:546-52. https://doi.org/10.1016/j.ttbdis.2019.01.007 PMID: 30709658

155. Bechah Y, Capo C, Mege JL, Raoult D. Epidemic typhus. Lancet Infect Dis. 2008; 8:417-26. https:// doi.org/10.1016/S1473-3099(08)70150-6 PMID: 18582834

156. Faucher JF, Socolovschi C, Aubry C, Chirouze C, Hustache-Mathieu L, Raoult D, Hoen B. Brill-Zinsser disease in Moroccan man, France, 2011. Emerg Infect Dis. 2012; 18:171-2. https://doi.org/10.3201/ eid1801.111057 PMID: 22261378 